\title{
Teaching NeuroImages: Sleep-related periodic breathing in acquired central sleep apnea
}

Massimo Marano, MD, Fioravante Capone, MD, Francesco Motolese, MD, Mario Tombini, MD, and Vincenzo Di Lazzaro, MD

Neurology ${ }^{\circledR}$ 2018;91:e1001-e1002. doi:10.1212/WNL.0000000000006131
Correspondence

Dr. Marano

m.marano@unicampus.it

Figure Clinical, radiologic, and polysomnographic findings

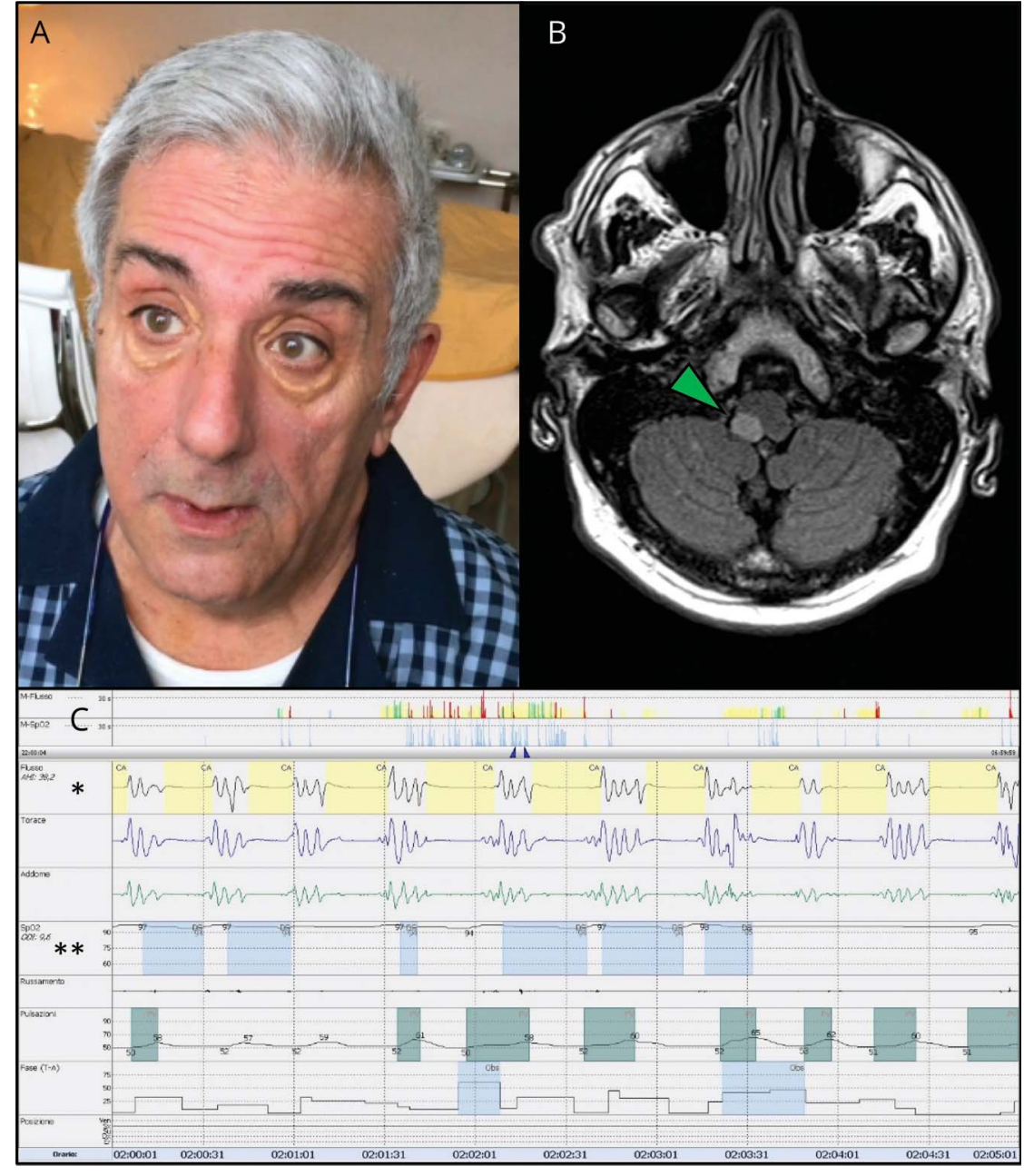

(A) The patient is forcefully opening his eyelids, showing slight right eyelid ptosis and enophthalmos suggestive of Horner syndrome. (B) Brain MRI (fluid-attenuated inversion recovery sequence) reveals right upper dorsal medullary hyperintense lesion (arrowhead). (C) Polysomnography (5-minute recording) shows an ataxic (Biot) breathing pattern embedded with central apnea (*airway flow), without significant blood oxygen loss (**saturimetry).
A 68-year-old man complained of the subtle onset of postural instability. A detailed investigation revealed the presence of ataxia with pulling to the right, right face and contralateral (left) trunk and limb hypoesthesia, slight dysphagia, right eyelid ptosis, and enophthalmos (figure, A) caused by medullary infarct (figure, B) (Wallenberg syndrome). Due to snoring, the patient underwent polysomnography, which showed central sleep apnea with Biot breathing ataxia (figure, C). Biot periodic breathing is an irregular, gasping respiration caused by respiratory pacemaker lesions, observed in comatose patients with bulbar damage. ${ }^{1}$ Here, Biot breathing presented in the context of central sleep

\section{MORE ONLINE}

\section{$\rightarrow$ Teaching slides}

links.lww.com/WNL/

A654 
apnea. ${ }^{2}$ Medullary breathing control circuit lesions impair autonomic respiration, which is critical for nighttime respiration.

\section{Acknowledgment}

The authors thank the patient and his family for their cooperation.

\section{Study funding}

No targeted funding reported.

\section{Disclosure}

The authors report no disclosures relevant to the manuscript. Go to Neurology.org/N for full disclosures.

\section{References}

1. Posner JB, Saper CB, Schiff ND, Plum F. Plum and Posner's Diagnosis of Stupor and Coma, 4th ed. New York: Oxford University Press; 2007.

2. Mendoza M, Latorre JG. Pearls and Oy-sters: reversible Ondine's curse in a case of lateral medullary infarction. Neurology 2013;80:e13-e16. 


\title{
Neurology
}

\author{
Teaching NeuroImages: Sleep-related periodic breathing in acquired central sleep \\ apnea \\ Massimo Marano, Fioravante Capone, Francesco Motolese, et al. \\ Neurology 2018;91;e1001-e1002 \\ DOI 10.1212/WNL.0000000000006131
}

This information is current as of September 3, 2018

Updated Information \& Services

References

Subspecialty Collections

Permissions \& Licensing

Reprints including high resolution figures, can be found at: http://n.neurology.org/content/91/10/e1001.full

This article cites 1 articles, 1 of which you can access for free at: http://n.neurology.org/content/91/10/e1001.full\#ref-list-1

This article, along with others on similar topics, appears in the following collection(s):

\section{All Cerebrovascular disease/Stroke}

http://n.neurology.org/cgi/collection/all_cerebrovascular_disease_strok e

Autonomic diseases

http://n.neurology.org/cgi/collection/autonomic_diseases

Coma

http://n.neurology.org/cgi/collection/coma

Eyelids

http://n.neurology.org/cgi/collection/eyelids

Sleep apnea

http://n.neurology.org/cgi/collection/sleep_apnea

Information about reproducing this article in parts (figures,tables) or in its entirety can be found online at:

http://www.neurology.org/about/about_the_journal\#permissions

Information about ordering reprints can be found online:

http://n.neurology.org/subscribers/advertise

Neurology ${ }^{\circledR}$ is the official journal of the American Academy of Neurology. Published continuously since 1951, it is now a weekly with 48 issues per year. Copyright (O 2018 American Academy of Neurology. All rights reserved. Print ISSN: 0028-3878. Online ISSN: 1526-632X.

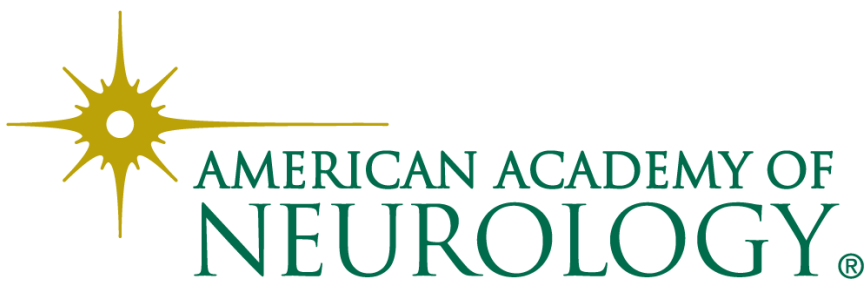

